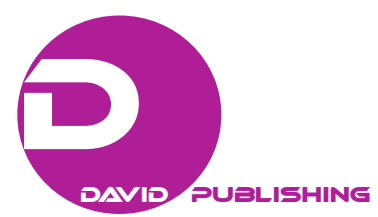

\title{
CBS and NBC Expand Nightly News to 30 Minutes: A History of the 1963 Expansion
}

\author{
Chelsie Akers \\ University of Arizona, Tucson, United States \\ D. Spencer Chalk \\ Brigham Young University, Provo, United States
}

\begin{abstract}
The year 1963 was pivotal for broadcast news. Walter Cronkite forever changed how the American people receive their news when he anchored the first 30 minute nightly news. During the 60s, television news had two strong rivals: the newspaper and the radio. The target audience for nightly newscasts was to a generation of people that were used to getting news elsewhere. Since people were familiar with getting the news from radio, news stations relayed the news the same way as it was done on the radio: as talking heads. In other words, the news stations used a trusted face to read the news to people without any improvements on presentation. This all changed when CBS and NBC saw a robust and lucrative future for the nightly news. This paper will outline the steps taken by the two networks to make an extended half hour evening news a reality.
\end{abstract}

Keywords: nightly news, Walter Cronkite, political conventions, Huntly-Brinkly, Telstar

As the invent of the television started to become a house hold item, television news became part of a home. Families everywhere in America circled around the television set to hear what the beloved and trusted news anchors had to share. One such news anchor was Walter Cronkite, a recipient of the William Allen White Award, a Peabody Award, an Emmy Award, the George Polk Award, and a Gold Medal Award, but most notably known as "the most trusted man in America" (Biography).

Not only was Walter Cronkite a fixed image in American broadcast news, he also took part in the evolution of broadcast news. One example of Cronkite's presence through a changing medium was when he broadcast the first ever 30 minute evening news. The morning of September 2, 1963 Walter Cronkite had a lot to get done, but he knew by the end of the day. He would have made history in the world of broadcast news. One of the first changes of the day was that he had to get his new desk ready. Before airing that evening, his studio would change to just a clear shot of his "U" shaped desk. The desk needed to be put in and the process to get a camera in his office had to be seamless. Once he oversaw that issue, he made his way over to the summer cottage of President Kennedy in Cape Cod to perform a recorded interview with the president. Cronkite then edited the film and prepared it for that evening's show. Finishing as much prep work as the day allowed, Cronkite combed his hair back, sat down in his chair, and at 6: $30 \mathrm{pm}$ for the first time ever said the words, "Good evening from our CBS news room in New York, on this, the first broadcast of network television's first

Chelsie Akers, doctoral student, Department of Communication, University of Arizona.

D. Spencer Chalk, M. A. student, Department of Mass Communication, Brigham Young University. 
daily half hour news program" (Applegate, 1992).

The only way for this momentous day to happen was through the power of the viewers. The 1939 world fair gave people in the United States the realization that television could be a regular household item (General Electric, 1996). However, the television did not become common in homes until the well into the 1950s. According to Time Magazine, "in 1948 only one American in ten had seen a television (Early Years of TV, 2012). The annual television report provides an example of the wide growth of television; it shows that in 1950 only $9 \%$ of Americans had a TV in their home, but $91.3 \%$ of Americans had a television set in the home by 1963 (See Figure 1). In just over one decade, the popularity of the television multiplied 100 fold, thus allowing for the expanded uses of the machine and its broadcasting forces.

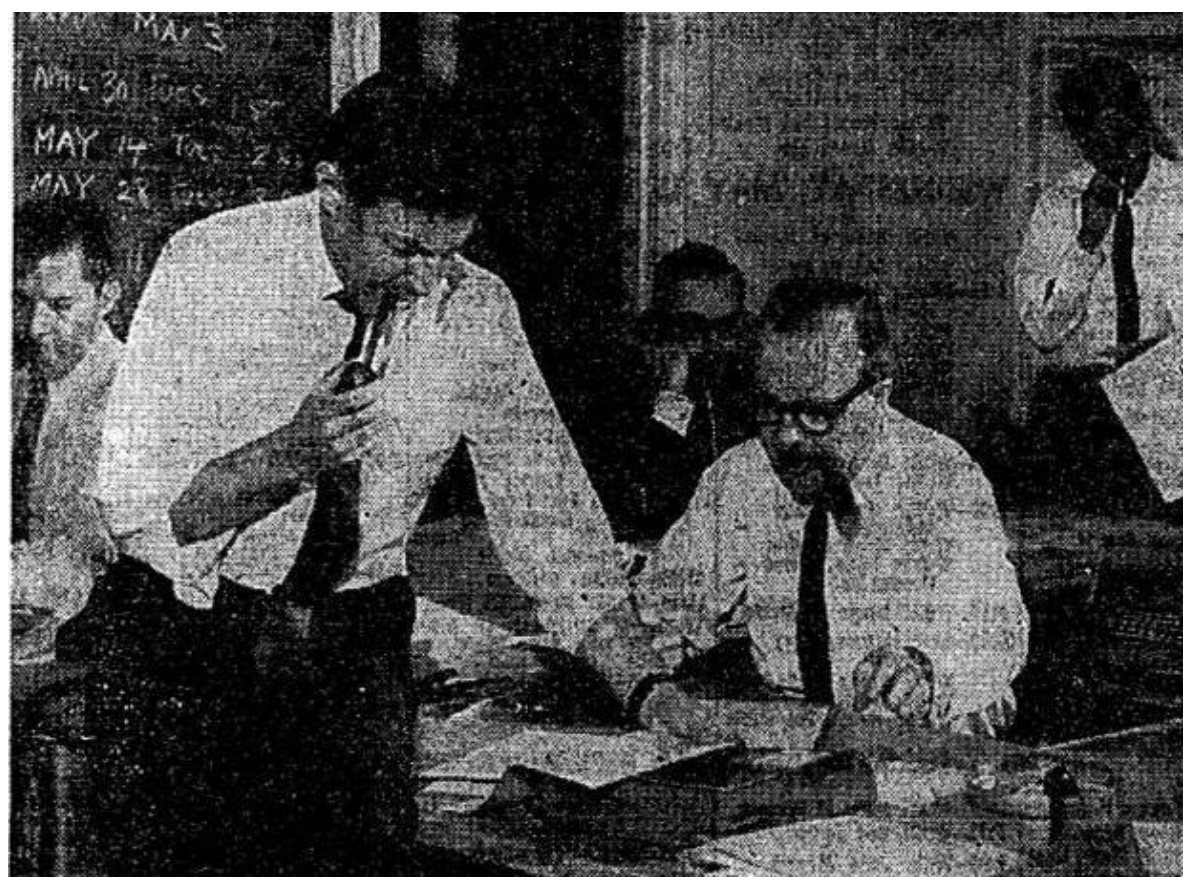

Figure 1. Don Hewitt and Walter Cronkite discussing expansion to 30 minutes photo from New York Times (Shanley, 1963).

Television was a new piece of technology that broadcasters analyze even today in order to get the picture with the best quality and most popular results to the viewers. When news stations started reporting the news in the 15 minute evening news format, their technology was still in the early stages; stations were limited to what they could film live and occasionally they would use film instead of the clean and direct live feed. Film, however, had to be developed and took time - a precious commodity in the business of breaking news stories (Bliss, 1991).

\section{Political Conventions}

One aspect of news stations is to cover the political conventions. The coverage of political conventions has changed its focus from the first televised convention in 1940 to the present. Part of the reason for the change has been because of the added technology available to political reporters. On June 10, 1924, the republican convention in Cleveland, Ohio was broadcast over the radio for the first time (Shedden, 2004). Before political conventions transmitted over the radio, their target audience was politicians; after 1924, however, with the 
conventions available to the public via radio, the average citizen in the United States became the most prevalent audience.

With the increasing demand for access to the presidential conventions, it was logical for the television news stations to jump on the broadcasting bandwagon. An affiliate of NBC experimented with coverage as early as 1940, but World War II temporarily halted any expansion of the convention coverage. After the War, when television news stations again fought for ratings, CBS and NBC took a risk and covered the 1952 convention.

Sig Mickelson, director of CBS News, decided that CBS would cover the convention. In 1951 coast to coast cable was initiated, which allowed for any station's live coverage to be broadcast across the entire country. The 1952 conventions were the first big events that warranted the use and unveiling of gavel to gavel coverage across the nation. Gavel to gavel coverage is the term coined in 1952, meaning that the news stations would have uninterrupted coverage over the political conventions from the opening gavel strike until the closing gavel strike. Mickelson also thought that it was necessary to use one reporter as the center for the coverage; it was through this planning that Mickelson coined the term "Anchorman" (Gates, 1978).

The job of CBS anchorman for the political conventions of 1952 was first given to Ed Murrow, but Murrow was leery of television news and did not want to be part of something that he believed would never be taken seriously. Instead, Cronkite got the job even with his limited broadcast experience. Cronkite took the assignment seriously and spent the beginning of the year reading up on all the candidates and that year's issues. The gavel to gavel coverage, Sig Mickelson's enthusiasm, Don Hewitt's ability to look outside the box, and Cronkite's charisma made the 1952 conventions a turning point in television news broadcast and in Cronkite's life. After this, the previously unknown Cronkite went on to anchor other news shows, including The Morning Show on CBS with a puppet named Charlemane (Gates, 1978). In addition, Cronkite hosted a CBS program entitled You Are There, a newstainment show that revolved around the re-creation of historical events and figures such as the fall of Rome, Michelangelo, and the signing of the Magna Carta. As a result of anchoring both of these shows, Cronkite's popularity grew.

NBC also covered the 1952 convention; however, they were unprepared for the conversations an anchorman would need to engage in because they had not done research on the politicians and their issues and their hosts were not nearly as entertaining as Cronkite. Ultimately, the 1952 conventions were more of a learning experience for NBC and they took the next four years to figure out how to make a bigger impact than CBS and Cronkite had made in 1952. Reuven Frank, director of NBC News, was assigned the task to make the broadcasting of the 1956 conventions monumental. With collaboration from radio broadcasters who had covered the previous conventions, Frank devised a plan to make the NBC gavel to gavel live coverage of the 1956 convention a success. Once the plan was in place, NBC had to decide on an anchorman because they felt CBS's previous success was based on Cronkite's strong onscreen presence. NBC deliberated for months because Frank knew the news's acceptance from other NBC divisions for the next four years relied on how well the convention was presented. David Huntley and Chet Brinkley were chosen as NBC's convention anchormen. The conventions turned out to be a great success for NBC and marked the start of the Huntley Brinkley Report - a program that was developed as competition for The CBS Evening News with Walter Cronkite, which, after years of perfecting, finally triumphed in ratings over Cronkite (Frank, 1991).

The early political conventions are what shaped televised news coverage to be what it is today. After a few failed attempts, both CBS and NBC realized the importance of having anchors with strong personalities, good 
looks, and adaptability. When viewers can relate to, trust, and even be entertained by the anchor they have a reason to go to the TV for news instead of a newspaper or even the radio.

\section{Announcement_-Idea of 30 Minutes Presented}

After the success of Cronkite and Huntley-Brinkley at the conventions, they each went on to have their own shows. On April 16, 1962, after stints on The Morning Show, You Are There, and The Twentieth Century, Walter Cronkite was hired by CBS to replace Doug Edwards as the anchor of their nightly news broadcast. Richard Salant, then president of CBS News, had the idea to hire Cronkite. He described Cronkite as "the stereotypical, traditional, hard-nosed, no-nonsense wire service reporter" (Buzenberg \& Buzenberg, 1999, p. 38). At the time Cronkite was relatively unknown. In 1988, Salant reflected on his decision to hire Cronkite:

We didn't pick Walter to anchor the Evening News because of his hairdo - he didn't have one. We didn't pick Walter because he was beautiful - he wasn't. We didn't pick Walter because [...] a focus group, wired up to a machine palpitated at the sight of him [...] we picked Walter for the only sound reason to choose an anchor. He was a real pro, a superb reporter - a newsman who always gave his audience an honest account, no matter what his personal beliefs. (as cited by Buzenberg \& Buzenberg, 1999, p. 37)

Also, on October 29, 1956 Huntley and Brinkley had their first 15 minute broadcast news show. Although the show was not an instant success, Huntley and Brinkley stayed together for over 15 years. According to Gates,

The NBC executives remained locked in the stalemate [of choosing between Huntley and Brinkley for position of anchor] for several weeks until one day, as they were thrashing out the problem for the umpteenth time, it suddenly dawned on them that there was no law preventing them from featuring two anchormen... The new team was born, and by the time the 1956 conventions were over, Chet Huntley and David Brinkley had become household names. (1978, p. 75)

CBS and Cronkite were up against NBC and the Huntley-Brinkley pair since the political conventions and with the idea of expanding the quarter hour news broadcast to a half an hour; they would once again be competing with each other.

The discussion of extending the length of programming was discussed at CBS and was officially announced May 5, 1963 in The New York Times with the following report: "Beginning in the fall, [Cronkite's] Monday-through-Friday news shows will be expanded to half-an-hour each evening. During the extra time, he hopes to do more stories in depth and features related to the news" (Shanley, 1963, para. 17). In 1963, Walter Cronkite was not yet the "most trusted man in America" and his CBS evening news program rated second to NBC's The Huntley-Brinkley Report (Bliss, 1991, p. 300). Executives at CBS decided to introduce the then novel idea of creating, producing, and broadcasting a 30 minute evening news program. This idea was viewed as "the only way to beat the Huntley-Brinkley [ratings] lead" (White, 1982, p. 172). The day of this announcement also changed NBC's vision. They had already been considering the idea of expanding to half an hour, but were not prepared to pioneer the change.

After six years at the Huntley-Brinkley show, Frank moved on and went to cover other news, wanting a change from the nightly news. Frank was in the documentary division of NBC news for only a few short months before CBS announced their shift to 30 minutes. Frank recalls the day of the announcement in the Times:

"What do you plan to do today?" - Robert Northshield 


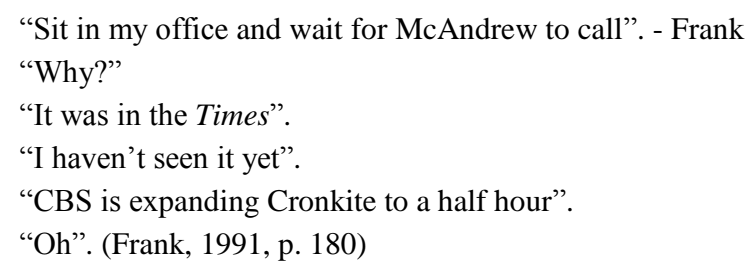

As Frank expected, President of NBC News, Bill McAndrew called him that day to ask him to come back and oversee the expansion of the Huntley-Brinkley report. Frank agreed to go back but only committed to two years.

The promise of expanded nightly news started a whirlwind of innovation in the broadcasting field. The technology available to news stations was finally catching up to the visions and expectations of broadcast news. Changes within this new technology made it more viable to make the successful transition to a 30 minute nightly news that possessed an increased focus on international news events. The need to switch to 30 minute broadcast was clearer than ever.

\section{Affiliates-Advertising Costs}

CBS executives knew the audience and subsequently the advertisers would be willing to support this extended news period. Local news affiliates were already broadcasting a 30 minute news program with success.

Since network news could not profitably be retained in prime time, the network's solution was to move it to the adjacent time period, which up to then was considered - by the affiliates at least — to be "affiliate time". (Epstein, 1973, p. 85)

The affiliate stations or local stations were hesitant and disinclined to embrace this time change. Affiliates would lose the advertising revenue to the network as a result of this new time slot. This change amplified the affiliates' unwillingness to transmit the networks' nightly news programming, because affiliates did not want to lose additional advertising revenue during the "prime time" evening programming. "You have to remember that this time period is gold to the local guys" (Epstein, 1973, p. 88). The affiliates depended on the "prime time" advertising revenue. The affiliates' reluctance to lose advertising revenue to a nightly news program intensified when both NBC and CBS decided to extend their 15 minute nightly news broadcast to 30 minutes. In anticipation of this dissatisfaction, NBC proposed a revenue strategy to compensate and subdue their affiliates for the deficiency of commercial time. With the affiliates subdued by the sharing of advertising revenue for the lost commercial time, CBS and NBC executives then focused on additional obstacles before the switch from to 30 minute news broadcast could come to fruition.

One such obstacle leading up to the extension of the nightly news broadcast was the audience's reaction to a longer news program. Television executives were uncertain of the level of success the new 30 minute news program could reach, hesitating because they were unsure that (1) there would be an adequate amount of news to satisfy the extra 15 minutes and (2) they "did not believe that viewers would sit still for a whole half hour" (Slater, 1988, p. 41). Despite these concerns, NBC's Frank believed viewers would watch a longer news program. In an interdepartmental memo Frank wrote, "[The] quarter-hour news succeeded despite itself because the audience wanted news," and that the American public "does not yet know [the news] can come in any other packages" (personal communication, January 18, 1963, p. 1). The affiliates also had misgivings with the effect the change would have on their viewers. They did not want to lose the advertising revenue as well as 
the ratings. Theodore White said, "[T]he reluctant affiliates found their audiences were not 'depressed' by news, but hungry for it” (As Cited by Johnston, 2003, p. 60). After the hesitation regarding affiliates' lost revenue, and the American public's reaction to the longer nightly news program, Salant of CBS and Frank of NBC additionally needed to address internal aspects involving the shift to 30 minutes.

\section{Developing}

CBS executive Salant knew this transition, although needed, would not come without its challenges. "During this early period, the mechanics of television...were cumbersome, primitive, and unreliable, so that each evening's broadcast was a hairy adventure" (Slater, 1988, p. 38). It was during this time that the news broadcast used "film" versus "tape". Film was cheaper, but took time to be developed, cut, and edited; moreover, film was awkward and bulky. The newer "tape" technology was still not widely understood and used; additionally, it was more expensive than its film counterpart. Camera technology was still in its infancy taking a while to turn on and thus making it difficult to capture footage of "breaking" news.

With talk of evening news expanding to 30 minutes, the stations started looking at better options. Videotape had been invented by then but was not widely used because the video camera was bulky and the tape was not as easy to edit as film (Stephens, 1980). In 1962 CBS and NBC started experimenting with the videotape process. The use of the videotape and its potential were viewed on CBS's first 30 minute evening news show, when Walter Cronkite interviewed President Kennedy earlier in the day at an offsite location and replayed the interview on the show's 30 minute premier (Bliss, 1991).

News stations did not start out developing their own film-instead, they contracted out to different companies; CBS used Telenews and NBC used Fox Movietone. By utilizing these companies, news stations were able to prearrange for newsworthy events to be filmed. The only time large unplanned events could be covered was when they lasted long enough for a film crew to arrive on location, such as wars, natural disasters, or other catastrophes (Gates, 1978). Eventually, in the late 50s, CBS started developing their own news film and hiring their own camera crews (Gates, 1978, p. 56).

News stations continued to use film even with the invention of the videotape, because it was cheaper and produced a better quality video at the time. News film worked by first filming the sequence on silent film. Then the voice-over was recorded while the film was being developed. The final show was ready when the two pieces were put together. This was the procedure even though technology for the time allowed for filming both the video and audio simultaneously. The drawback of simultaneous recording was that the camera could not move - it had to focus on the reporter and could not pan around to capture graphics, or scenery. This nonmoving reporter stance became known as the "Stand-upper" (Gates, 1978, p. 61). Hewitt changed all this with his invention of the double projector system. This allowed for the use of a video camera and a voice camera at the same time and then the reels could be mixed together when they were being developed (Gates, 1978).

We live in a world where a quick scanning of the headlines is no longer adequate, a world of intricate scientific and technical advances, of sensitive and volatile political relationships, of deep and widespread social change. CBS News conceived and developed the half hour concept in order to report this fast-moving constantly changing world in greater depth and broader scope. (as cited by Bliss, 1991, p. 300)

The change to videotape also allowed for video to be shot off location in New York or Chicago then instantly sent over telephone line to the studio to be broadcast that same night. 


\section{Telstar}

Soon after, there was the shift to satellite when Telstar sent the first satellite into orbit for the sole purpose of communications. It was early in the morning, 4: 35 am on July 10, 1962 when the rocket holding Telstar was launched and only 11 minutes later at 4: 46 am, it was in orbit, forever changing television as it had been known (Solomon, 1962). This satellite of 15,000 parts and 170 pounds is an incredibly significant sphere with only a 34.5 inch diameter. Telstar's 45 million dollar experiment was proven successful by its fifth orbit when the tracking antenna picked up the beeping beacon of the satellite (Solomon, 1962, p. 10). It was exactly 7: 31 $\mathrm{pm}$ when the history of television would forever be changed as the picture of the American flag with the Star Spangled Banner playing in the background was transmitted from Andover Main to Holmdel New Jersey. Telstar was just the beginning for public communication in the satellite revolution. Telstar is a low earth orbit and did not orbit the earth at the same rate the earth moves so only allowed transmission at selected times during the day. Just a few years after Telstar, in 1963, Syncom Two was launched as the first geosynchronous satellite to orbit Earth.

New technology, as well as economic feasibility, encouraged change. Cameras were smaller and more portable. Communications satellites were coming into being. So was color television. Videotape had arrived. The time was ripe to branch out and expand. (Bliss, 1991, p. 300)

\section{Bureaus}

Before the shift into satellite use, CBS was only able to keep three domestic bureaus: New York, Washington, and Chicago (Gates, 1978). With the use of satellite CBS was able to expand their offsite bureaus to include Los Angeles, Atlanta, and Dallas. Each of these bureaus were stocked with the station's own equipment instead of having to share with different networks or with the radio broadcast equipment.

Frank envisioned the 30 minute nightly news revolving around a central collection of individuals in New York and Washington. This central group would include editors, directors, and writers (personal communication, January 18, 1963). Each location would possess a camera, crew, and basic broadcaster. Four international bureaus-Asia, Latin American, and two in Europe-would be created to facilitate America's growing interest in news outside of the United States. Frank envisioned "[t]he core group possess[ing] specialists in science, business, social stress, and other national fields as well as defense, diplomacy, and similar specialties for the Washington reporters" (personal communication, January 18, 1963, p. 9). Expanding the workforce successfully would not evade frustration and problems of their own. Sending reporters and cameramen abroad also meant that the technology to broadcast from Europe, Asia, and Latin America needed to be available.

When moving to a half hour program, one of Frank's first requirements was for the staff be substantially expanded in order to handle "two or three pieces of original picture reporting a day" (Frank, personal communication, January 18, 1963, p. 8). Up until this time in news, it was common for newscasters to be used on multiple shows during the week. Frank made it mandatory that with the expansion to 30 minutes, each newscaster would work exclusively on their assigned show. Frank also declared that "the stars of the show must be the program itself" (personal communication, January 18, 1963, p.11).

\section{Content/Format Change}

With the changes in technology and setting within both CBS and NBC, there was also a need to change 
the content that was delivered. While the debate to expand the evening news forged on, there were weekly shows such as Eye Witness and Sunday News Special, which reported main stories from around the world in a thirty minute format. These shows offered more of what was happening in the world to the viewers than they were able to get in a 15 minute skim of the news. In an article from Variety (1962), Cronkite and Midgley point out that the stories they air on Friday night are frequently such big news that they show up the following Tuesday on Time and Newsweek. Cronkite said in the interview with Variety about Eyewitness, that, "our editorial coverage [...] is to throw things out the window because of a later breaking story. Such things happen on the average of every other week". If there were half hour news programs every evening, then there would be less need to throw out good stories, just because there is a newer story.

Both CBS and NBC executives were unclear on the format that would constitute the change to a 30 minute news program. Salant knew that the new 30 minute format "could not have just twice as many stories" as the current fifteen-minute broadcast had, "nor could it have the same number of stories, each twice as long" (Salant, p. 41). Both CBS and NBC executives understood that an innovative program structure needed to accompany the momentous shifting to a 30 minute news broadcast. NBC's Frank thought that if the transition to a 30 minute news broadcast was to succeed, then the entire news format needed to change: "What we are talking about must be big, different, and individual, and look big, different, and individual. If not, why disturb existing success?" (Frank, personal communication, January 18, 1963, p. 2).

In an interoffice memo, Frank said, "If the half hour is aimed at giving the viewer more of the same, it will not only drive him away, it will stifle for a long time this fully logical movement toward a new and expanded form" (personal communication, January 18, 1963, p. 6). Frank saw the potential impact the 30 minute news program could have on the television news medium. He understood that television could elevate television journalism comparable to the Life magazines elevation of "picture journalism". Frank noted that the height of radio was during the Second World War and the years directly before and after the war; however, after that, radio news-broadcasting format transitioned to the television. Frank also found other obstacles with the 15 minute news program, specifically that "the length is wrong; the time of day is wrong" (Frank, personal communication, January 18, 1963, p. 1).

Much on the same lines, Ernest Leiser, known for inventing the CBS half hour format, said that his purpose was to give the viewer's something new, "to leave off the compressed tabloid treatment of hard news on TV and to give our viewers instead the television equivalent of an authoritative and complete daily newspaper" (As cited by Slater, 1988, p. 210). Additionally, Leiser embraced this understanding and envisioned the news format to be "an entirely new kind of broadcast with new meaning and a new scope" (Salant, p. 41).

Both Frank and Leiser understood that Americans would watch the news and if it were presented correctly, they would watch the news instead of reading the newspaper. One main reason is because the television news has a unique ability to present the news differently than newspapers. Instead of telling people that there are people starving around the world, "television can show hunger" (Frank, personal communication, January 18, 1963, p. 7).

Public opinion polls during the early 60s discovered that the American people increasingly relied on the television as their major source for news. During the years preceding the extended news slot, "news was thought to be the cheapest way of filling [space]" (Epstein, p. 85). The nightly news aired around 7: 30-8:00 pm because this time slot, according to Epstein (p. 85), preceded "prime time" and relieved the difficulty for the 
network to sell commercial time at "prime time" rates. As television audiences strengthened, so did the "primetime" block. This resulted in the nightly news being shifted to an earlier time slot. In order to successfully transition from a 15 to 30 minute news broadcast and incorporate the proposed format changes, the network needed to change times; currently they were forced to compete with children's television programming and were broadcasting during the average family's dinner time, which did not contribute to the cultivation of a demanding audience.

\section{Benefits}

As a result of the newly available technology, shift in significance of TV news, and possible revenue, CBS announced in 1963 that their evening news with Walter Cronkite would expand to a 30 minute broadcast in September of that year. This was followed a week later by the expansion of NBC's Huntley-Brinkley Report to a half hour.

The most significant effect this change made for the two networks was the extra five minutes of commercial time. By adding 15 extra minutes to the news, five of those minutes were allocated to commercial time. According to Epstein, the networks were able to sell the extra minutes for $\$ 28,000$ per minute, totaling a revenue of 36 million dollars a year (1973). When the networks took the minutes from the affiliates, the affiliates did not want to lose their revenues from the commercials they could have sold, so in order to complete the agreement to get the extra 15 minutes, the networks promised the affiliates a source of compensation; CBS is reported to have given them nine million dollars a year in "compensation" (Epstein, 1973). Once the cost of the show, fees, and compensation is taken out of the revenue, one network made 13 million dollars in profit in one year of the expanded 30 minute evening news. As Epstein said, "Those extra minutes made news profitable" (1973, pp. 87-88).

Since the news was now able to make money, huge shifts happened within the industry following the shift to a half hour. The days of having the news sponsored by companies were over. This can be seen as a positive shift because the intentional or unintentional biases would no longer be placed on the producers and writers to censor their stories. An example of such biases can be seen in the film Good Night and Good Luck, a movie based on a real life conflict Ed Murrow faced as he confronted Joseph McCarthy: Murrow risked his career by covering the story on Milo Radulavitch, who was fired from the air force for not denouncing his parents and sister because they were rumored communists. The sponsor for Murrow's show was Alcoa, and Alcoa has military ties and would not pay for the ads if they ran the story on Radulavitch. Murrow and Fred Friendly, CBS president, ended up splitting the three thousand dollars for the ads and ran the show. Even though the network claimed to not have biases or be subject to censorship, Murrow was taken off his show after his duel with McCarthy.

This single example of how the news was influenced by having a sponsor is what the public knows about. How many other stories were pushed aside to appease a network sponsor? The simple effect of the news making a profit made a remarkable difference to the network news industry by allowing them to be rid of sponsors and therefore produce a more reliable news broadcast.

\section{Conclusion}

One might think it would not be a big deal to change a newscast from 15 minutes to 30 minutes. However, there were many steps that had to be taken in order to be ready for the first ever half hour nightly news that 
September night. The technology had to be prepared and ready, schedules had to be changed, money had to be redistributed, deals had to be struck, studios had to be equipped, news anchors chosen, earlier segments recorded, all before the infamous countdown began: "3...2...1...Action".

The idea for a half hour nightly news hung in the air for years before coming to fruition because the means to make it happen just were not there. Technology was a constant challenge. Although there were new technologies developing quickly, it never seemed quick enough. Live recording was too cumbersome and time consuming. Tape recording was too hard to edit. Pre-recording was apparently impossible because the voice recording could not happen simultaneously. For the half hour nightly news to take off and be successful, many people had to start using unfamiliar machinery and become experts on their functions and never imagined qualities. Also, Telstar had to be invented and in orbit to make a coast to coast broadcast possible.

All of this is one example of how an idea paired with determination at the right time and right place, can change history. When Cronkite said those words "Good evening from our CBS news room in New York, on this, the first broadcast of network television's first daily half hour news program" (Applegate, 1992). Now, 50 years later, the American people still rely on the half hour nightly news to keep them informed on daily events.

\section{References}

Applegate, B. (Producer). (1992, September 2). Up to the minute. [Television news broadcast]. New York, NY: CBS Broadcasting Company.

Biography of Walter Cronkite (n.d.). ASU: Walter Cronkite School of Journalism and Mass Communication. Retrieved October 29, 2013 from http://cronkite.asu.edu/walter/waltercronkite.php

Bliss, E. (1991). Now the news: The story of broadcast journalism. Oxford, NY: Columbia University Press.

Buzenberg, S., \& Buzenberg, B. (Eds.). (1999). Salant, CBS, and the battle for the soul of broadcast journalism: The memoirs of Richard S. Salant. Boulder, CO: Westview Press.

Early Years of TV. (2012). Time Archive. Retrieved from http://www.time.com/time/archive/collections/0,21428,c_television_history,00.shtml

Epstein, E. (1973). News from nowhere: Television and the news. New York, NY: Random House.

Frank, R. (1991). Out of thin air: The brief wonderful life of network news. New York, NY: Simon \& Schuster.

Gates, G. (1978). Air time: The inside story of CBS News. New York, NY: Harper \& Row.

General Electric. (1996). 1939 New York world fair. Retrieved October $4, \quad 2012 \quad$ from http://www.1939nyworldsfair.com/worlds_fair/wf_tour/zone-5/general_electric.htm

Johnston, L. (2003). “Good night, Chet:” A biography of Chet Huntley. Jefferson, NC: McFarland \& Company, Inc.

New York Times. (1963). [Don Hewitt and Walter Cronkite Photograph]. Retrieved from http://search.proquest.com/docview/116579218?accountid=4488

Shanley, J. (1963, May 12). Cronkite: Experienced newsman on the air. New York Times. Retrieved from http://search.proquest.com/docview/116579218?accountid=4488

Shedden, D. (2004, September 1). The first convention broadcast: Radio at the 1924 convention. Poynter. Retrieved from http://www.poynter.org/uncategorized/25177/the-first-convention-broadcast-radio-at-the-1924-conventions/

Slater, R. (1988). This...is CBS: A chronicle of 60 years. Englewood, NJ: Prentice Hall.

Stephens, M. (1980). Broadcast news: Radio journalism and an introduction to television. Dallas, TX: Holt, Rinehart and Winston.

Solomon, L. (1962). Telstar: Communication break-through by satellite. New York, NY: McGraw-Hill Book Company, Inc.

Television Facts and Statistics 1939-2000 (n.d.). TVhistory.tv. Retrieved from http://www.tvhistory.tv/Annual_TV_Households_50-78.JPG

Variety (1962, January 3). Cronkite and Midgley: I love Luce-id.

White, T. (1982). America in search of itself: The making of the president 1956-1980. New York, NY: Harper \& Row. 